\title{
Transformation of the groundwater composition in coastal zone of the Ivankovo reservoir during 20 years
}

\author{
Elena Lapina ${ }^{*}$, Larisa Lapina ${ }^{1}$, Vera Kudryashova ${ }^{1}$
}

${ }^{1}$ Water Problems Institute, Russian Academy of Sciences, Russia, 119333, Moscow, str. Gubkina, 3; e-mail: *shtriter_elena@rambler.ru

\section{Трансформация на състава на подземните води в крайбрежната зона на язовир Иванково за 20 години}

Елена Лапина, Лариса Лапина, Вера Кудрямова

Lapina, E., L. Lapina, V. Kudryashova. 2021. Transformation of the groundwater composition in coastal zone of the Ivankovo reservoir during 20 years. Engineering Geology and Hydrogeology, $35,3-14$.

\begin{abstract}
The Ivankovo reservoir is an important source of drinking water for the city of Moscow. The water quality status of aquifers around the reservoir is important for its safety, as groundwater inflow into the reservoir is considerable. The chemical composition of the shallow groundwater around the Ivankovo reservoir is studied. The study is based on long-term monitoring (1999-2019) of both surface and groundwater quality. The aim of the paper is to identify changes in groundwater quality over this period and to determine their causes. The results show that over this 20 year-period, the groundwater quality in the study area shifted from $\mathrm{HCO}_{3}-\mathrm{Ca}$ to $\mathrm{HCO}_{3}-\mathrm{Ca}-\mathrm{Mg}$ type, proven by statistical methods. The median values of the total dissolved solids (TDS) decreased by $13 \%$ in summer and by $17 \%$ in winter. It is shown that the ongoing processes of transformation of the groundwater chemical composition are mainly due to climate change, and atmospheric precipitation in the spring-winter period is a possible source of the $\mathrm{Mg}^{2+}$ ion entering the groundwater table. Among other components, concentrations of chlorides and sulfates underwent the largest change, the median values of which have decreased by two or more times, which is caused by both the dilution of the groundwater by melt water and a decrease in the anthropogenic load.
\end{abstract}

Keywords: groundwater quality, climatic changes, Ivankovo reservoir, Moscow City.

Резюме. Язовирът Иванково е основният източник за непрекъснато водоснабдяване за гр. Москва. Качеството на подземните води около язовира е важно за неговата безопасност, тъй като притокът на подземни води във водоема е значителен. Изследван е химичният състав на грунтовите води в крайбрежната зона на язовира. Проучването се основава на дългосрочен качествен мониторинг на повърхностните и подземни води (1999-2019 г.). Целта на статията е да се идентифицират промените в качеството на подземните води през този период и да се установят причините за тях. Резултатите показват, че през този 20-годишен период съставът на подземните води в изследваната зона се е изменил от $\mathrm{HCO}_{3}-\mathrm{Ca}$ към $\mathrm{HCO}_{3}-\mathrm{Ca}-\mathrm{Mg}$ тип, което е 
доказано чрез статистически методи. Средните стойности на минерализация намаляват с 13\% през лятото и със $17 \%$ през зимата. Показано е, че протичащите процеси на трансформация на химичния състав на подземните води се дължат основно на климатичните промени, а атмосферните валежи през пролетно-зимния период са възможен източник за навлизане на йона $\mathrm{Mg}^{2+}$ в подземните води. Сред останалите компоненти най-голяма промяна претьрпяха концентрациите на хлориди и сулфати, чиито средни стойности са намалели два или повече пъти, което се дължи както на разреждането на подземните води с вода от топенето на снега, така и на намаляването на антропогенното натоварване.

Ключови думи: качество на подземните води, климатични промени, язовир Иванково, гр. Москва.

\section{Introduction}

The Ivankovo reservoir is located in the Upper Volga Basin on a stretch Tver - Dubna, in southeastern part of the Tver region. Geographically, it is confined to the Upper Volga Lowland. The study area occupies northwestern part of the Moscow artesian basin. The reservoir is one of the main sources of drinking water supply for Moscow metropolis. Water quality status of aquifers around the reservoir is important for its safety, as groundwater inflow into the reservoir is considerable.

The climate of the study area is temperate continental, average monthly temperature of the warmest month is $+17.8^{\circ} \mathrm{C}$, the coldest - minus $9.8^{\circ} \mathrm{C}$. Over past 30 years, there has been an increase in air temperatures, especially during the winter months; the annual precipitation is $550-700 \mathrm{~mm}$ (Lapina, Grigorieva, 2020). For the Ivankovo reservoir, the share of groundwater inflow is considerable, as groundwater contribution to the river flow in the region is $32 \%$ (Abakumov et al., 2000). The regional flow of groundwater is directed to the largest drain - Volga River.

The aim of the study is to identify changes in water quality of groundwater supplying the reservoir over the period 1999-2019 and to determine possible causes of this transformation.

\section{Materials and Method of analysis}

The study is based on our own data on water quality monitoring, carried out in winter and summer periods of 1999-2000 and 2018-2019 around the Ivankovo reservoir, within the terraces above the floodplain in residential areas.

Monitoring sites include dug wells, springs and surface waters, including snow water. The monitoring wells are shallow (from 4 to $8 \mathrm{~m}$ on average), reinforced with concrete rings; they are used for water supply. The data base of this study encompasses chemical composition of waters in 63 wells during summer period and 47 wells during winter low-water period.

Chemical analyzes were performed at the accredited chemical laboratory of the Ivankovskaya Research Station of the Institute of Water Problems at the Russian Academy of Sciences on the day after sampling. Concentrations of Cl-ion were determined by argentometrical method, $\mathrm{HCO}_{3}^{-}, \mathrm{Ca}^{2+}, \mathrm{Mg}^{2+}$ ions - by titrimetric method, $\mathrm{SO}_{4}{ }^{2-}$ ion - by turbidimetric method with $\mathrm{BaCl}_{2}, \mathrm{Na}^{+}$and $\mathrm{K}^{+}$ions - using potentiometric method.

The work uses methods of field research and statistical analysis. To eliminate influence of specific features of geological conditions and anthropogenic load on the assessment of groundwater quality, the same wells were selected from the entire data set. Correctness of the comparison of the survey results is justified by the choice of objects only with a terrace regime and similarity of moisture content in previous years during compared periods.

To confirm the hypotheses put forward, we used the data of long-term regime observations at the Ivankovo reservoir (Ploski - cross-section AB), its tributary - the Donkhovka River (Selikhovo alignment), the Shumnovo bog and supporting springs. 


\section{Geological and hydrogeological conditions}

Location of the study area near the Ivankovo reservoir is presented on Fig. 1. Monitoring sites are shown along with position of cross-section $\mathrm{AB}$.

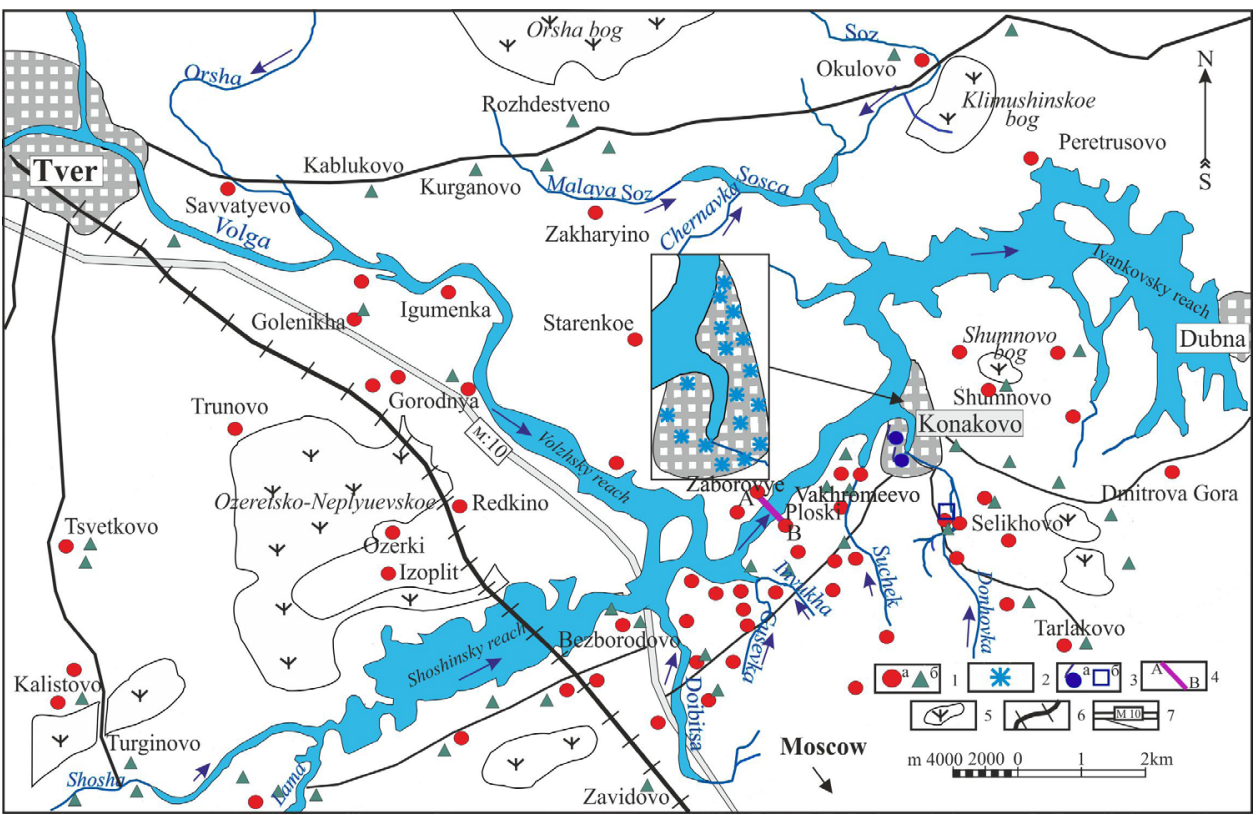

Fig. 1. Location of the study area.

1 - sampled wells: in summer (a), in winter (b); 2 - locations of snow sampling (2009); 3 - regime spring (a) or well (b); 4 - cross-section line; 5 - bogs; 6 - railway; 7 - car roads.

A

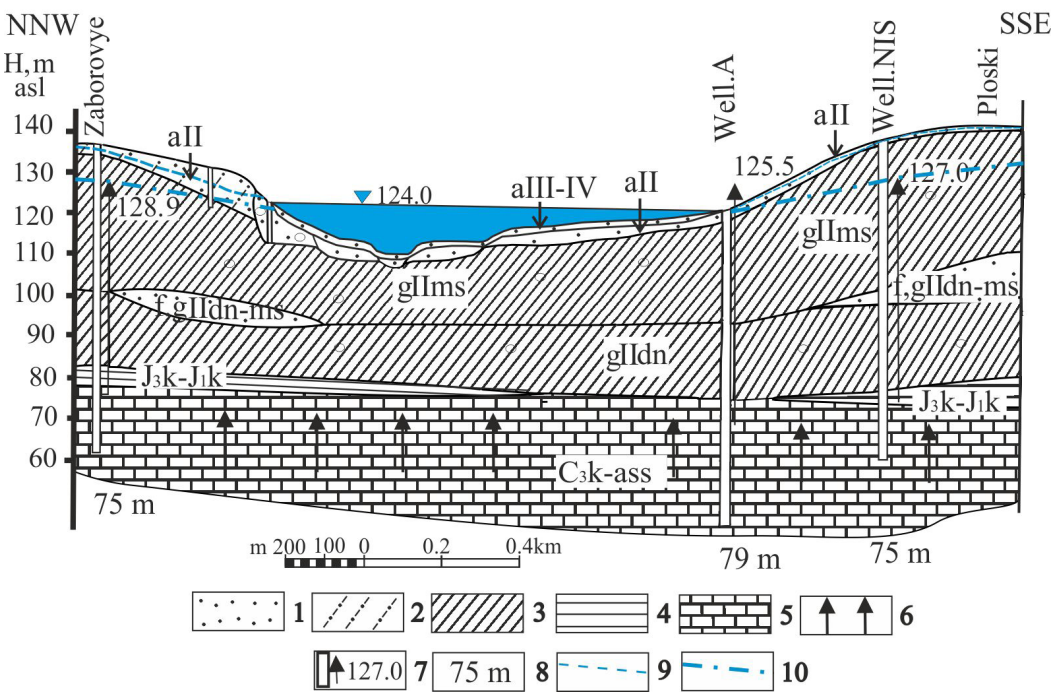

Fig. 2. Geological and hydrogeological cross-section along the AB line.

1 -sands, 2 - sandy loam, 3 - moraine loams, 4 - Jurassic clays, 5 - limestones, 6 - ascending groundwater flow, 7 - well (borehole). Numerals at wells (to the right): absolute altitudes of the piezometric surface, 8 - depth of the well, 9 - groundwater level, 10 - piezometric level of the Klyazma-Assel aquifer $\mathrm{C}_{3} \mathrm{k}$. 
The geological and hydrogeological cross-section $\mathrm{AB}$ is shown on Fig. 2. Jurassic clays underlie the Quaternary deposits, below are deposits of Carboniferous limestones and dolomites. Quaternary deposits are presented by the Moscow glacial sands and moraine clay loams, 40-100 m thick. Water-bearing sands are divided by moraine into several horizons (Kovalevsky, 2001; Lapina et al., 2014). Within the Volga floodplain terraces, the Quaternary aquifers are hydraulically connected, and in case of small thickness of the underlying Jurassic clays or their erosion, they receive inflow from the Upper Carboniferous aquifer (Fig. 2).

The relief of the territory is weakly dissected, the absolute altitudes of surface vary from 124 to $149 \mathrm{~m}$, the minimum marks are observed near the edge of the river Volga. The depth of groundwater table varies from $0.2-0.5 \mathrm{~m}$ in relief depressions to $15.0 \mathrm{~m}$ in interfluves (2.5-5.0 $\mathrm{m}$ on average), in the coastal zone 2.0-3.0 m. Springs flow rates are in the range $0.01-0.7 \mathrm{~L} / \mathrm{s}$ (Lapina et al., 2014).

The ground waters of the region are mostly fresh, with neutral $\mathrm{pH}$ or slightly alkaline. In the vicinity of the village of Zavidovo brackish waters are found related to the zone of tectonic fracturing. The groundwater from the sampled wells is from the complex alluvial-fluvioglacial aquifer; most part of shallow groundwater from the wells and springs receive ascending inflow from the confined Upper Carboniferous aquifer. Long-term average chemical composition of waters from different genesis is presented in Table 1.

Chemical composition of groundwater in Table 1 is represented by spring waters (and not by groundwater from wells), since it is the natural discharge that gives an integral characteristic of the groundwater flow (Zlobina et al., 2017).

The least TDS content is for melt water with the color values from 0 to 15 degrees, and TDS content - from 12 to $40 \mathrm{mg} / \mathrm{L}$. Of the considered water bodies, the highest color value is for the waters of bogs, which receive water from precipitation and thus have a low TDS content. In the series of unconfined - semi-confined - confined waters, the highest color value is observed in the waters of intermoraine fluvioglacial aquifers with a weak local pressure.

Table 1. Long-term average physico-chemical parameters of different water types natural waters for the period 2006-2019 (mg/L)

\begin{tabular}{|l|l|l|l|l|l|c|}
\hline Water body & snow & mire & river & \multicolumn{3}{|c|}{ groundwater } \\
\hline & melt & bog & Volga & unconfined & semi-confined & confined \\
\hline $\begin{array}{l}\text { Object / } \\
\text { Parameter }\end{array}$ & Konakovo & Shumnovo & Ploski & $\begin{array}{l}\text { Spring, } \\
\text { pine forest }\end{array}$ & $\begin{array}{l}\text { Spring, park } \\
\text { entrance }\end{array}$ & artesian \\
\hline $\mathrm{HCO}_{3}^{-}$ & 18 & 24 & 172 & 155 & 187 & 322 \\
\hline $\mathrm{Ca}^{2+}$ & 4.4 & 6.4 & 39.7 & 40.7 & 54.5 & 66.8 \\
\hline $\mathrm{Mg}^{2+}$ & 1.6 & 3.6 & 11.8 & 8.7 & 11.8 & 22.6 \\
\hline $\mathrm{K}^{+}$ & 0.1 & 0.3 & 1.2 & 0.6 & 4.2 & 0.3 \\
\hline $\mathrm{Na}^{+}$ & 5.1 & 4.4 & 4.3 & 1.6 & 6.6 & 0.7 \\
\hline $\mathrm{SO}_{4}^{2-}$ & 4.5 & 4.7 & 10.7 & 14 & 23 & 6 \\
\hline $\mathrm{Cl}^{-}$ & 3.2 & 2.2 & 7.9 & 3 & 15 & 2.4 \\
\hline $\mathrm{Color}^{*}$ & 6 & 225 & 40 & 6 & 35 & 16 \\
\hline $\mathrm{TDS}^{2}$ & 37 & 45 & 248 & 223 & 297 & 429 \\
\hline
\end{tabular}

* degrees, on the Pt-Co scale 


\section{Results and discussion}

\section{Dynamics of the class and type of groundwater}

The studied waters belong mainly to the hydrocarbonate class (according to $\mathrm{O}$. Alekin), with a TDS of $0.4-0.8 \mathrm{~g} / \mathrm{L}$ on average. The classification of O.A. Alekin put the principle of predominant ions and the relationship between ions. The predominant ions are considered to be the ones with the highest relative content as a percentage in terms of the amount of the equivalent substance (Posokhov, 1985). Table 2 shows the distribution of groundwater wells by classes for the winter and summer low-water periods.

Table 2. Distribution of well waters by classes, years and seasons (in \%)

\begin{tabular}{|l|c|c|c|c|c|c|}
\hline \multirow{2}{*}{ seasons } & \multicolumn{5}{|c|}{ Classes of groundwater (according to O. A. Alekin) } \\
\cline { 2 - 7 } & \multicolumn{2}{|c|}{ hydrocarbonate class } & \multicolumn{2}{c|}{ sulfate class } & \multicolumn{2}{c|}{ chloride class } \\
\hline Years & $1999-2000$ & $2018-2019$ & $1999-2000$ & $2018-2019$ & $1999-2000$ & $2018-2019$ \\
\hline Winter (47)* & 88 & 96 & 0 & 0 & 12 & 2 \\
\hline Summer (63) & 92 & 97 & 4 & 0 & 4 & 3 \\
\hline
\end{tabular}

* - the number of tested wells

During winter low-flow period, no sulfate class waters were found. The share of chloride-class waters over 20 years has decreased from $12 \%$ to $2 \%$, and that of hydrocarbonate - has increased from $88 \%$ to $96 \%$. At the beginning of this century, the share of sulfate-class waters in summer low-water period was only $4 \%$; at present, hydrocarbonate class waters make up $97 \%$ of the total amount tested wells, and the rest belong to the chloride class. Previous studies have found that the decrease in concentration of sulfates and chlorides in groundwater is due to the decline in industry and agriculture in the region (Lapina et al., 2014; Lapina, Grigorieva, 2020).

The transformation of groundwater chemical composition is most noticeable when the results of analyses are presented by the formula of M.G. Kurlov (the name of the groundwater type is given by ions in decreasing order of their content) (Posokhov, 1985). Twenty years ago during the summer low water period, groundwater of a bicarbonate calcium $(27 \%)$ and bicarbonate calcium-magnesium (25\%) types prevailed almost equally among the sampled wells. In summer of 2019, the ratio changed in favor of $\mathrm{HCO}_{3}-\mathrm{Ca}-\mathrm{Mg}$ waters (up to $57 \%$ of total number of the sampled wells). The share of $\mathrm{HCO}_{3}-\mathrm{Ca}$ waters decreased to $19 \%$. In winter 2018/2019, among the well samples, $\mathrm{HCO}_{3}-\mathrm{Mg}$ and $\mathrm{HCO}_{3}-\mathrm{Cl} \mathrm{Mg-Ca}$ waters types were registered, which were absent 20 years ago.

\section{Statistical analysis}

For the study area, the concentrations of chloride, sulfate, hydrocarbonate, potassium, sodium, calcium, magnesium, as well TDS content and color values are analyzed by statistical methods.

The entire data set was divided into four groups according to seasonal and temporal characteristics: winter 1999/2000 and 2018/2019, summer 1999 and 2019. For each group of data, the main statistical characteristics were calculated, presented in Table 3.

In the last column of the table changes in median values are shown (i.e. differences between 1999 and 2019 values). The hydrochemical parameters of the region do not obey the normal distribution law, therefore the median is a more informative characteristic than the average. The only one of all parameters for which there is a positive increase in the median values is magnesium, and the increase is observed only during the summer period. 
Table 3. Descriptive statistics of the groundwater quality parameters, $\mathrm{mg} / \mathrm{L}$ (in the numerator - data for 1999, in the denominator - for 2019)

\begin{tabular}{|c|c|c|c|c|c|c|}
\hline Parameters & Max & Min & Mean & Median & $\begin{array}{l}\text { Standard } \\
\text { deviation }\end{array}$ & $\begin{array}{l}\text { Change of } \\
\text { median }\end{array}$ \\
\hline \multicolumn{7}{|c|}{ Winter $1999 / 2019(n=47)$} \\
\hline $\mathrm{Cl}^{-}$ & $400 / 228$ & $1 / 3$ & $80 / 47$ & $52 / 21$ & $88 / 60$ & -31 \\
\hline $\mathrm{SO}_{4}{ }^{2-}$ & $328 / 117$ & $13.5 / 4$ & $88 / 37$ & $69 / 32$ & $72 / 24$ & -37 \\
\hline $\mathrm{HCO}_{3}{ }^{-}$ & $780 / 634$ & $61 / 128$ & $403 / 374$ & $378 / 366$ & $159 / 139$ & -12 \\
\hline $\mathrm{K}^{+}$ & $420 / 71$ & $0.10 / 0.45$ & $32.9 / 11.3$ & $13.7 / 8$ & $65.7 / 13.3$ & -5.7 \\
\hline $\mathrm{Na}^{+}$ & $220 / 67$ & $0.4 / 2.3$ & $31.7 / 11.8$ & $18 / 8.5$ & $38 / 11.8$ & -9.5 \\
\hline $\mathrm{Mg}^{2+}$ & $61 / 106.9$ & $4.9 / 5.1$ & $33.75 / 33.3$ & $36.6 / 30.6$ & $13.9 / 19.8$ & -6 \\
\hline $\mathrm{Ca}^{2+}$ & $188 / 160$ & $3 / 19$ & $108 / 89$ & $110 / 87$ & $39 / 31$ & -23 \\
\hline TDS & $1868 / 1143$ & $389 / 255$ & $810 / 627$ & $718 / 597$ & $337 / 220$ & -121 \\
\hline color* & $100 / 35$ & $7 / 5$ & $45.6 / 12.9$ & $40 / 10$ & $24.4 / 7.8$ & -30 \\
\hline \multicolumn{7}{|c|}{ Summer 1999/2019 $(n=63)$} \\
\hline $\mathrm{Cl}^{-}$ & $297 / 311$ & $0 / 3$ & $35 / 35$ & $23 / 16$ & $50 / 56$ & -7 \\
\hline $\mathrm{SO}_{4}^{2-}$ & $212 / 86$ & $11 / 3$ & $75 / 30$ & $60 / 27$ & $53 / 21$ & -33 \\
\hline $\mathrm{HCO}_{3}^{-}$ & $842 / 853$ & $91 / 98$ & $347 / 363$ & $348 / 342$ & $126 / 130$ & -6 \\
\hline $\mathrm{K}^{+}$ & $172 / 104$ & $0.10 / 0.20$ & $27.5 / 15.7$ & $10 / 9.5$ & $35.7 / 20.7$ & -0.5 \\
\hline $\mathrm{Na}^{+}$ & $110 / 153$ & $0.2 / 1.5$ & $31 / 26.5$ & $25 / 17.7$ & $27 / 28$ & -7.3 \\
\hline $\mathrm{Mg}^{2+}$ & $63.44 / 78$ & $4.88 / 6.44$ & $22.5 / 29.4$ & $20.7 / 25.5$ & $12.4 / 15.6$ & +4.8 \\
\hline $\mathrm{Ca}^{2+}$ & $184 / 168$ & $22 / 26$ & $90 / 85$ & $92 / 80$ & $35 / 33$ & -12 \\
\hline TDS & $1284 / 1221$ & $225 / 181$ & $665 / 601$ & $659 / 573$ & $189 / 212$ & -86 \\
\hline color* & $180 / 100$ & $0 / 5$ & $23 / 165.8$ & $17 / 10$ & $30 / 16.5$ & -7 \\
\hline
\end{tabular}

* degrees, on the Pt-Co scale

According to our calculations, a significant decrease in median values occurred for the TDS in winter (by 17\%) and summer (by 13\%) periods; color values decreased by $75 \%$ and $41 \%$, respectively. The most likely reason for this decline is the dilution of the shallow groundwater during snowmelt. The increase in the number of thaws and its effect on the characteristics of groundwater in winter is noted in many works (Kovalevsky, 1994; Borevsky, Markov, 2014; Grinevsky, Pozdnyakov, 2017; Smolyar, 2017).

In particular, in (Grinevsky, Pozdnyakov, 2017) it is shown that in the southwestern part of the Moscow artesian basin, climatic changes lead to increase in the average long-term recharge of groundwater by 20-30 mm/year. It was found that such an increase in recharge is associated with a rise of air temperature in the cold period, which contributes to the flow of thawed water into the soil, which, in the absence of transpiration and bioaccumulation during this period, enters the groundwater practically without losses.

A significant decrease in median values was noted for concentrations of sulfate in winter (by 54\%) and in summer - by 55\%. Chloride concentrations in winter decreased to a greater extent than in summer: $60 \%$ versus $30 \%$. The decrease in these two parameters, known as technogenic markers, has been observed concurrently with the decline in industry and agriculture. 
Comparison of the groundwater quality in wells was carried out between 1999 and 2019 , that is, with a break of 20 years. To confirm the revealed trends, data from long-term regime observations of various water bodies were used. One of the several complex hydrological stations is located in the village of Selihovo, where year-round observations of the well, the spring and the Donhovka River (the right tributary of the Ivankovo reservoir) have been carried out since 1999 (Fig. 1). The well is located 400 $\mathrm{m}$ from the river's bank, on the left bank of the fluvial terrace; the depth of the well is $6.5 \mathrm{~m}$. Figure 3 shows variations of the average annual concentrations of chloride and sulfate in the well from 1999 to 2020, in figure 4 - in the river flow (surface, channel) from 1999 to 2019.

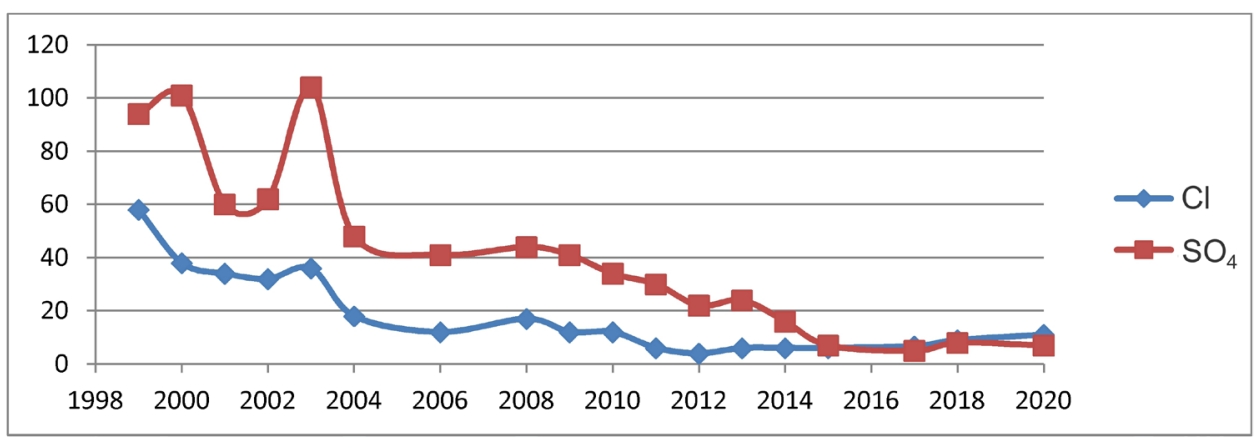

Fig. 3. Variations of average annual concentrations of sulfate and chloride ions for the period 1999-2020, regime well at Selikhovo.

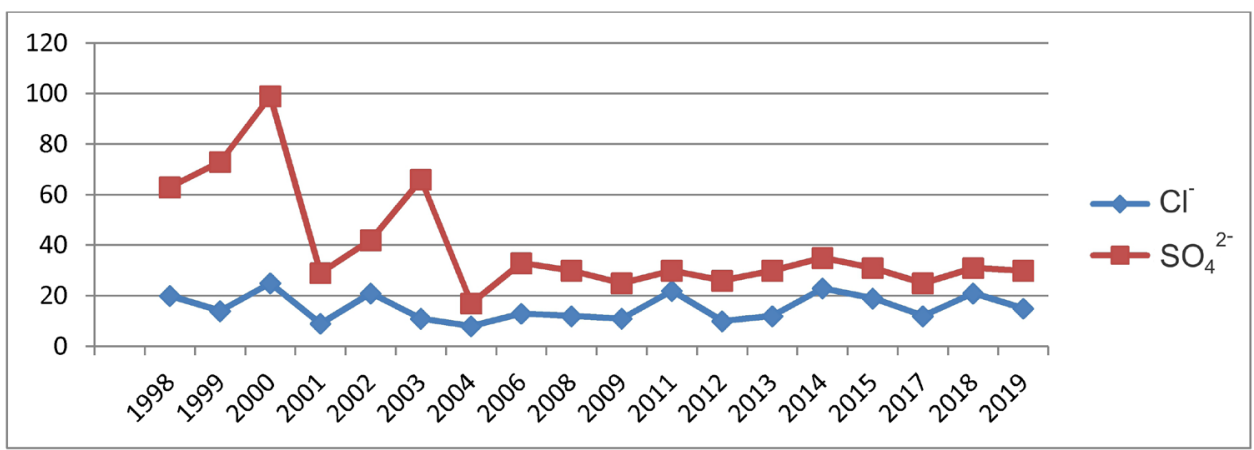

Fig. 4. Variations of average annual concentrations of sulfate and chloride ions or the period 1999-2020, Donkhovka river, Selikhovo alignment.

The groundwater from the well shows a monotonic trend towards a decrease for both sulfates and chlorides. Contrarily, the river waters are with stable content of the chloride ion during the entire observation period. Such stability can be related to the use of a sand-salt mixture on the roads, which with melt water flows into the river with surface runoff at the onset of floods.

For comparison, the variations of average annual concentrations of $\mathrm{Mg}_{2}{ }^{+}$and $\mathrm{Ca}_{2}{ }^{+}$ ions in the water from the same well for the period 1998-2020 are presented in figure 5 , which clearly confirms the results of statistical calculations in a separate regime object.

In statistics, the standard deviation is a measure of the variation of a data set. The lower its value, the more homogeneous the data. The largest decrease in this parameter in winter is registered for $\mathrm{SO}_{4}{ }^{-}, \mathrm{Cl}^{-}, \mathrm{K}^{+}, \mathrm{Na}^{+}$ions and the color value. For the $\mathrm{Mg}_{2}{ }^{+}$ ion, this parameter shows an increase. In the summer period, there was an increase in $\mathrm{Cl}^{-}, \mathrm{HCO}_{3}{ }^{-}, \mathrm{Mg}_{2}{ }^{+}$ions and TDS, a decrease - for $\mathrm{SO}_{4}{ }^{2-}, \mathrm{K}^{+}$ions and color values. The median values for the $\mathrm{HCO}_{3}{ }^{-}$and $\mathrm{Na}^{+}$ions are practically unchanged. 


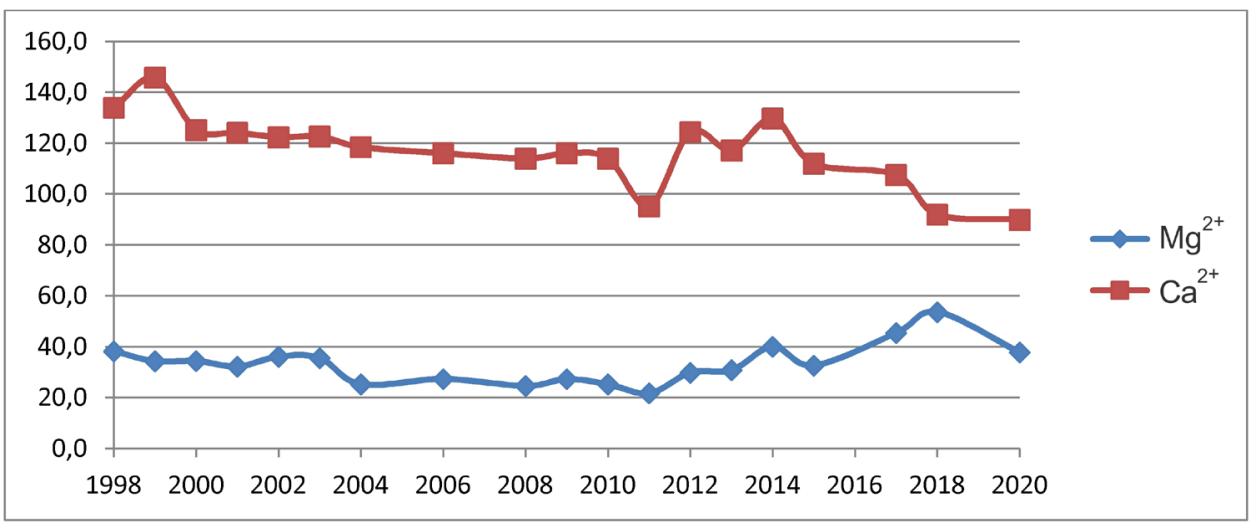

Fig. 5. Variations of average annual concentrations of $\mathrm{Mg}^{2+}$ and $\mathrm{Ca}^{2+}$ ions, regime well at Selikhovo, 1998-2020.

Thus, the statistical analysis of the data showed that over the past 20 years, the concentrations of all chemical components of groundwater, as well as the values of color and TDS, have decreased during the winter low-water period.

The most significant decrease is for the concentrations of sulfate and chloride. One of the reasons for this decrease is the decline in anthropogenic load in the study area. In the summer period, there was an increase in the concentration of magnesium, the content of other components decreased, although less significantly in comparison with winter period.

The established fact indicates the dilution of groundwater by waters of more frequent thaws, which is most clearly evidenced by the widespread drop in color values and TDS in the winter period (see Table 1).

The question remains about the reasons for the increase in the proportion of magnesium in the cationic composition during the summer low-water period. Possible sources and reasons for the input of excess magnesium into groundwater are as follows:

- civil activities in the catchment area of the Ivankovo reservoir;

- intensification of leaching processes in the Upper Carboniferous water-bearing rocks, represented by alternating limestones and dolomites, due to an increase in winter air temperatures;

- atmospheric precipitation containing dusty particles of calcium and magnesium carbonates.

\section{Influence of the degree of anthropogenic load on the dynamics of the concentration of the $\mathrm{Mg}^{2+}$ ion}

The reason for the increase in proportion of magnesium may be drilling and subsequent operation of unauthorized deep wells by owners of country houses. Due to the lack of insulating casing support, there can be a behind-the-casing overflow of water saturated with magnesium from the underlying aquifer. However, such changes occur only locally, but we are faced with an spatial transformation of the groundwater composition.

When using magnesium fertilizers (dolomite flour, magnesium oxide), magnesium that is not used by the root system of plants can penetrate into groundwater. Inquiries to the Agronomic Service of the region made it possible to reject this assumption magnesium fertilizers are not used in the region.

The hydrochemical survey of groundwater was carried out around the reservoir. The level of anthropogenic load on its shores is very different: the right bank is subject to high anthropogenic load. Here are the federal highway M-10 Moscow St. Petersburg, Oktyabrskaya railway, Konakovo town, urban-type settlements with 
industrial enterprises, a large agricultural association "Dmitrova Gora", horticultural associations. On the left bank there are only former rare villages that have become summer cottages, and the regional highway Tver - Kimry.

As an example of range in magnesium concentrations, let us consider the dynamics of the chemical composition of groundwater in individual wells by seasons and years, taking into account the anthropogenic pressure on the left and right banks of the reservoir (Table 4).

Table 4. Changes in the chemical composition of groundwater over 20 years

\begin{tabular}{|c|c|c|c|}
\hline season & year & Sampling site, anthrop. pressure & Kurlov's formula, mmol \% \\
\hline \multirow{4}{*}{ 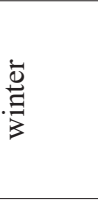 } & 1999 & \multirow{2}{*}{$\begin{array}{l}\text { Kablukovo, left bank, } \\
\text { cottages, highway }\end{array}$} & $\mathrm{M}_{0.54} \mathrm{HCO}_{3} 93$ / Ca51Na30K14 \\
\hline & 2018 & & $\mathrm{M}_{0.37} \mathrm{HCO}_{3} 82 / \mathrm{Ca} 72 \mathrm{Mg} 24$ \\
\hline & 1999 & \multirow{2}{*}{$\begin{array}{l}\text { v.Vakhromeevo, highway, dachas, } \\
\text { vegetable gardens, right bank }\end{array}$} & $\mathrm{M}_{0.69} \mathrm{HCO}_{3} 89 / \mathrm{Ca} 83$ \\
\hline & 2019 & & $\mathrm{M}_{0.63} \mathrm{HCO}_{3} 89$ / Ca79Mg18 \\
\hline \multirow{4}{*}{ 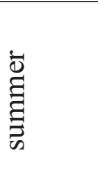 } & 2000 & \multirow{2}{*}{$\begin{array}{l}\text { v.Shumnovo, right bank } \\
\text { agriculture, bog }\end{array}$} & $\mathrm{M}_{0.66} \mathrm{HCO}_{3} 69 \mathrm{SO} 426 / \mathrm{Ca} 67 \mathrm{Mg} 23$ \\
\hline & 2019 & & $\mathrm{M}_{0.49} \mathrm{HCO} 397 / \mathrm{Ca} 46 \mathrm{Mg} 37 \mathrm{Na} 13$ \\
\hline & 1999 & \multirow{2}{*}{$\begin{array}{l}\text { v.Starenkoe, left bank, } \\
\text { cotages, highway }\end{array}$} & $\mathrm{M}_{0.49} \mathrm{HCO}_{3} 76 \mathrm{SO} 423 / \mathrm{Ca} 34 \mathrm{~K} 33 \mathrm{Na} 20 \mathrm{Mg} 14$ \\
\hline & 2019 & & $\mathrm{M}_{0.34} \mathrm{HCO}_{3} 85 / \mathrm{Ca} 62 \mathrm{Mg} 25$ \\
\hline
\end{tabular}

Comparison of the chemical composition of groundwater shows that at present in the water of most wells both in winter and summer low-water periods, magnesium ion either appeared where it was previously present in insignificant amounts (v. Vakhromeevo), or its share has noticeably increased (v. Starenkoe). Consequently, the change in the ratio of cations occurred regardless of the degree of anthropogenic load.

Against the background of an increase in the concentration of magnesium in groundwater, a natural question arises about the change in its content in adjacent water bodies of the same system. Table 5 summarizes the data on the average annual concentrations of the $\mathrm{Mg}^{2+}$ ion in tributaries, reservoir, bog, soil, groundwater and atmospheric waters according to our own and literature data.

Table 5. Average annual concentrations of $\mathrm{Ca}^{2+} / \mathrm{Mg}^{2+}$ ions $(\mathrm{mg} / \mathrm{L})$ in various water bodies for the periods 1999-2000 and 2018-2020

\begin{tabular}{|c|c|c|c|c|c|}
\hline Object & Name & Location & Characteristic & 1999 & 2019 \\
\hline mire & Shumnovskoe & $\begin{array}{l}\text { v. Shum- } \\
\text { novo }\end{array}$ & bog & $12 / 2.4$ & $6.4 / 6.8$ \\
\hline reservoir & Ivankovo & Ploski & right bank & $47 / 10.6$ & $39 / 11.4$ \\
\hline precipitation & rain & Konakovo & north-east & $4.0 / 1.2$ & $4.2 / 2.9$ \\
\hline soils & $\begin{array}{l}\text { Lysimetric } \\
\text { water }\end{array}$ & Ploski & turf soils & \multicolumn{2}{|c|}{$\begin{array}{c}\text { 16/3.7 (Motuzova et al., } \\
2010 \text { ) }\end{array}$} \\
\hline \multirow[t]{2}{*}{ groundwater } & unconfined & \multirow{2}{*}{$\begin{array}{l}\text { Pine forest } \\
\text { Konakovo }\end{array}$} & floodplain terrace & $47 / 8.5$ & $40 / 9.7$ \\
\hline & semi-confined & & park entrance & $52 / 9.8$ & $67 / 16.6$ \\
\hline artesian & self-flowing & Ploski & $\begin{array}{l}\text { Waterfront, well } \\
\text { A }\end{array}$ & $70 / 25$ & $64 / 24$ \\
\hline rivers & Donkhovka & Selikhovo & right tributary & $52 / 15$ & $61 / 18$ \\
\hline
\end{tabular}


Table 5 shows that the concentrations of $\mathrm{Mg}^{2+}$ ion in surface water bodies increased most significantly in bog waters, and in groundwater - in the intermoraine aquifer. Soil waters of fluvial terraces are characterized by low median values of calcium and magnesium and, in comparison with other components, have a higher coefficient of biological absorption, and therefore cannot cause an increase in magnesium in groundwater (Motuzova et al., 2010).

The available regime observations of the hydrochemical composition of well $\mathrm{A}$ (Klyazminsko-Assel aquifer of the Upper Carboniferous $\mathrm{C}_{3} \mathrm{k}$ ) make it possible to clarify the dynamics of magnesium concentration in confined waters for the period 19982020. The data set was divided according to seasonal and temporal characteristics. Statistical analysis of the array of hydrochemical data for well A showed low variability of magnesium concentration both by the seasons and over two decades of observations (Table 6).

Table 6. Median values of $\mathrm{Mg}^{2+}$ ion concentrations in the waters of the Ivankovo reservoir (right bank, surface) and in the confined waters of the Upper Carboniferous aquifer $\left(\mathrm{C}_{3} \mathrm{k}\right)$

\begin{tabular}{|c|c|c|c|}
\hline \multicolumn{4}{|c|}{ Ivankovo reservoir, Ploski - cross-section AB } \\
\hline \multicolumn{2}{|c|}{$1996-2006$} & \multicolumn{2}{|c|}{$2008-2020$} \\
\hline winter & summer & winter & summer \\
\hline 13.1 & 8.5 & 11.0 & 10.3 \\
\hline \multicolumn{4}{|c|}{ Artesian well A, reservoir bank, Ploski, aquifer $\mathrm{C}_{3} \mathrm{k}$} \\
\hline \multicolumn{2}{|c|}{$1998-2007$} & \multicolumn{2}{|c|}{$2008-2020$} \\
\hline 25.7 & 23.2 & 22.7 & 22.6 \\
\hline
\end{tabular}

Over the years of observations, there were no changes in the magnesium content in the upper confined aquifer, therefore, confined waters could not affect the increase in the proportion of magnesium in shallow groundwater. In the water of the reservoir, the median values of the ion slightly decreased in winter and increased in summer, which repeats the tendencies of changes in the magnesium content in the shallow groundwater of the catchment.

\section{Atmospheric precipitation}

The main process of changing the composition of stale snow is the dissolution of calcium and magnesium carbonates, which can fall into the snow with dusty particles (Krasintseva et al., 1977). A chemical analysis of freshly fallen and stale snow near a regime spring (2009) showed an increase in the magnesium content from 0.6 in January to $1.83 \mathrm{mg} / \mathrm{L}$ in March. The results of snow surveys carried out by the authors within the city of Konakovo in March 2009 (the points of snow sampling are indicated in the inset, Fig. 1), revealed the absence of calcium ion in $94 \%$ of the samples; magnesium concentrations were in the range of $1.22-1.83 \mathrm{mg} / \mathrm{L}$.

In 2018, according to (Komissarov, Chekmareva, 2019), the results of snow surveys at the same object gave an interval of magnesium concentrations of $0.5-1.0$ $\mathrm{mg} / \mathrm{L}$, which once again confirms the high variability of the chemical composition of precipitation (Posokhov, 1985).

Our observations of the groundwater level regime in wells on the fluvial terraces near the reservoir showed that in spring the melt snow water flows to the water table in impulse, and the level rises at once by $0.2-0.25 \mathrm{~m}$. Along macropores, cracks, worms' passages, the melt water containing magnesium flows directly to the water table or stays for a short time in the poorly permeable layers of the unsaturated zone, subsequently moving downward with infiltration waters. Calculation of the content of 
magnesium ion in melted snow waters with an average height of stale snow of $30 \mathrm{~cm}$ and an average moisture content of $100 \mathrm{~mm}$ (Mirzoev, Mirzoev, 1995) in the territory of Konakovo with an area of $38 \mathrm{~km}^{2}$ gives a figure of 4.64 tons, which will be $400 \mathrm{mg}$ per $1 \mathrm{~m}^{2}$ of the city area.

During the warm season, increased concentrations of magnesium in rainfall waters are periodically observed, which, together with the results of the snow surveys in 2009 and 2018, suggests a transit route for its entry in shallow groundwater, since the composition of precipitation in the area of work is more often $\mathrm{HCO}_{3}-\mathrm{Ca}$ (Motuzova et al., 2010; Lapina et al., 2014). Because precipitation containing magnesium passes in transit, an increase in magnesium is also observed on the left bank, where there is practically no anthropogenic load.

The most compelling evidence for the hypothesis of magnesium input into groundwater in the spring-winter period is the observed change in the chemical composition of the waters of the Shumnovo bog, which is fed only by precipitation. Starting from the extremely dry year 2014, magnesium predominates in the cationic series of bog waters (Lapina, 2021). The drainage waters of the bog have a constant hydrocarbonate calcium-magnesium composition, while the bog water, for example, on October 16, 2019, belongs to the bicarbonate magnesium type and, according to the Kurlov formula, is expressed as $\mathrm{M}_{0.09} \mathrm{HCO}_{3} 82 \mathrm{SO}_{4} 10 / \mathrm{Mg} 75 \mathrm{Ca} 18$ (\% mmol).

\section{Conclusions}

The study is based on long-term monitoring (1999-2019) of both surface and groundwater quality around the Ivankovo reservoir, an important source of drinking water for the city of Moscow. For a period of 20 years, the dominant composition of the shallow groundwater in the study area has been replaced from $\mathrm{HCO}_{3}-\mathrm{Ca}$ to $\mathrm{HCO}_{3}-$ $\mathrm{Ca}-\mathrm{Mg}$.

It was found by statistical methods that from 1999 to 2019, median values of TDS content decreased by $13 \%$ in summer and by $17 \%$ in winter, contents of chloride and sulfate - by half, concentrations of other components also decreased, but to a lesser extent. The most likely reason for the detected changes is dilution of groundwater by thawed in spring-winter period, which is associated with increase in number of thaws and increase in winter temperatures. A sharp decrease in the contents of chloride and sulfate is additionally due to a decrease in anthropogenic load.

Of all the components of the chemical composition in the shallow groundwater, the increase in concentration was found only for magnesium ion in summer. It has been established that the growth of magnesium in the groundwater of the fluvial terraces of the Ivankovo reservoir is caused by its input with atmospheric precipitation.

\section{Acknowledgements}

The work was carried out within the framework of the theme No. 0147-2019-0002 (state registration No. AAAA-A18-118022090104-8) of the State task of the IWP RAS.

\section{References}

Abakumov, V.A., N.P. Akhmetyeva, V.F. Brekhovskikh and others. 2000. Ivankovo Reservoir: Contemporary Condition and Problems of Protection. Khublaryan M.G. (editor in chief), Moscow, Nauka, 344 p. (in Russian).

Borevsky, B.V., M.L. Markov. 2014. Is low-water discharge of rivers a measure of groundwater recharge or total groundwater flow. Exploration and protection of subsoil, 5, Moscow, FBGU "VIMS", 10-16 (in Russian). 
Grinevsky, S.O., S.P. Pozdnyakov. 2017. A retrospective analysis of the impact of climate change on groundwater resources. Vestnik Moskovskogo Universiteta, Seriya 4: Geologiya, 2017, 2, 42-50 (in Russian with English abstract).

Komissarov, A.B., E.A. Chekmareva. 2019. Assessment of the quality of snow cover in the catchment area of the Ivankovskoye reservoir. Ecological collection. 7: Proceedings of the Mol. scientists. Vseros. pier conf. Togliatti: IEVB RAS, "Anna", 238-242 (in Russian).

Kovalevsky, V.S. 1994. The impact of changes in hydrogeological conditions on the environment. Moscow, Nauka, 138 p. (in Russian).

Kovalevsky, V.S. 2001. Combined use of surface and groundwater resources. Moscow: Scientific world, 332 p. (in Russian).

Krasintseva, V.V., N.P. Kuzmina, M.M. Senyavin. 1977. Formation of the mineral composition of river waters (on the example of three rivers of the central regions of the European part of the USSR). Moscow, Nauka, 176 p. (in Russian).

Lapina, E.E. 2021. Dynamics of the hydrochemical composition of depleted raised bogs (Tver region). In: Materials conf. "XI Galkin Readings" SPb: BIN RAN, 130-131 (in Russian).

Lapina E.E., N.P. Akhmetyeva, V.V. Kudryashova. 2014. Springs of the upper Volga valley and its tributaries: conditions of formation, regime, protection. OOO Kupol, Tver, 256 p. (in Russian).

Lapina, L.E., I.L. Grigorieva. 2020. Analysis of changes in air temperature and precipitation according to the data of weather stations Staritsa and Tver over a long period. Bulletin of Tver University. Series "Geography and Geoecology", 3 (31), 57-78 (in Russian with English abstract), https://doi.org/10.26456/22267719-2020-3-59-80.

Mirzoev, E.S., A.E. Mirzoev. 1995. Konakovsky district. Local history reference book. Tver. 330 p. (in Russian).

Motuzova, G.V., N.Yu. Barsova, E.A. Karpova, A.G. Kocharyan. 2010. Formation of the chemical composition of soil waters in the coastal zone of the Ivankovo reservoir. Izvestiya Rossiiskoi akademii nauk. Seriya geograficheskaya, 3, 109117 (in Russian with English abstract).

Posokhov E.V. 1985. Ionic composition of natural waters. Genesis and Evolution. Leningrad, Gidrometeoizdat, 254 p. (in Russian).

Smolyar, V.A. 2017. Forecast of changes in groundwater resources under the influence of climatic conditions. Geology and conservation of mineral resources, No. 4 (65), 60-66 (in Russian).

Zlobina, V.L., Yu.A. Medovar, I.O. Yushmanov. 2017. Transformation of the composition and properties of groundwater when the environment changes. Moscow, Publishing house "World of Science", 191 p. (in Russian).

Постьпила: 20.09.2021

Приета: 25.10.2021
Received: 20 September 2021 Accepted: 25 October 2021 